\section{Differences in the Incidence of Microscopic Polyangiitis and Granulomatosis with Polyangiitis (Wegener's). Is There a Latitudinal Gradient?}

To the Editor:

The small-vessel vasculitides associated with antineutrophil cytoplasmic antibodies (AASV) are a group of rare conditions characterized by inflammation and necrosis of blood vessel walls. The etiology of these conditions is largely unknown, but genetic and environmental factors have been related with the pathogenesis of AASV. Clues to the role of the environmental factors have been obtained by comparison of the incidence of the various entities of the AASV in different regions of the world ${ }^{1,2}$. Although evidence suggests that the overall incidence of AASV is similar throughout Europe $^{3,4}$, reports support the idea of a north-south gradient of the granulomatosis with polyangiitis (Wegener's) (GPA)/microscopic polyangiitis (MPA) ratio. GPA would be more common in the northern regions of the continent ${ }^{1,2,4,5}$, and MPA more common in the southern regions ${ }^{1,2,6}$. This latitudinal gradient is also documented in the Southern Hemisphere ${ }^{7}$.

These differences of topographic incidence might indicate a difference in pathogenesis between GPA and MPA due to the role of little-known environmental factors ${ }^{1,8}$. Gatenby and colleagues ${ }^{9}$ published a review of epidemiologic studies that describes the association between ambient ultraviolet (UV) radiation levels and the incidence of AASV. UV radiation has been suggested as a protective immunomodulatory factor on the onset of GPA that could explain the increase of the crude incidence rate with latitude observed for GPA. That study ${ }^{9}$ did not show an association of incidence of MPA with latitude.

To analyze the world distribution of the GPA/MPA ratio and the presence of a possible latitudinal gradient we obtained data of a systematic review of current evidence ${ }^{10}$ that include series with all the GPA and MPA patients attended in a referral center. Studies were identified by searching the Medline database via PubMed (1966 to 2009) and the Embase database via Ovid (1980 to 2009). The full electronic search strategies are described in the systematic review ${ }^{10}$. Using all the data, we created a world map showing percentage of GPA and MPA in each geographic area (Figure 1). We also added separately the percentage corresponding to patients with renal-limited vasculitis when they were included in the study sample. The identity of the geographic location is shown in a black box when all the patients had renal involvement. References for articles cited are given in Table 1.

Figure 1 shows the relationship between MPA and GPA in different locations. In Europe, there is a greater proportion of MPA in the south, in the Greek, Slovenian, and Spanish series, while GPA is more frequent in the north in the Czech, Danish, Dutch, French, German, Norwegian, and Swiss series. However, in the south an Italian series showed a greater proportion of GPA, and in the north, the Irish series showed an equal distribution of both entities. The 4 English series and the 2 Swedish series have a heterogeneous distribution. In these 2 countries, differences could be influenced by the design of the studies, with MPA predominance in the renal series and GPA predominance in the nonrenal series. Data for GPA/MPA ratios from the rest of the world are sparse.

These data emphasize a latitudinal gradient for the GPA/MPA ratio, as a major proportion of MPA in the majority of the south Europe series and a major proportion of GPA in the central Europe series are shown. However, the heterogeneous result of the English series and the results of the Swedish, Irish, and Italian series make it difficult to draw conclusions. Moreover, the majority of the reports illustrated in Figure 1 were not designed to obtain epidemiological variables (incidence and prevalence), the data are not adjusted by variables related with incidence of AASV such as sex, age or ethnicity, and many of them do not have complete case ascer- tainment. Population-based studies would be needed to test this association between latitude and disease.

In Europe, the GPA/MPA ratio shows a latitudinal gradient in the majority of published reports, although the exceptions make it difficult to confirm this north-south association. Examination of this ratio would yield interesting clues to the pathogenesis of AASV and would permit analysis of the interplay between genes and environment for both diseases.

LUIS CORRAL-GUDINO, MD, PhD, Department of Internal

Medicine, Hospital el Bierzo, Ponferrada, León;

MARIA BORAO-CENGOTITA-BENGOA, MD, Department of Internal Medicine; JOSE LUIS LERMA-MARQUEZ, MD, PhD, Department of Nephrology; JAVIER del PINO-MONTES, MD, PhD, Professor, Department of Rheumatology, Hospital Universitario de Salamanca, Salamanca, Spain.

Address correspondence to Dr. L. Corral-Gudino, Department of Internal Medicine, Hospital el Bierzo, c/o Médicos sin Fronteras, 7, CP:

24411, Fuentesneuvas, Ponferrada, León, Spain.

E-mail:lcorral@saludcastillayleon.es

\section{REFERENCES}

1. Watts RA, Gonzalez-Gay MA, Lane SE, Garcia-Porrua C, Bentham G, Scott DG. Geoepidemiology of systemic vasculitis: comparison of the incidence in two regions of Europe. Ann Rheum Dis 2001;60:170-2.

2. Watts RA, Lane SE, Scott DG, Koldingsnes W, Nossent H, Gonzalez-Gay MA, et al. Epidemiology of vasculitis in Europe. Ann Rheum Dis 2001;60:1156-7.

3. de Lind van Wijngaarden RA, van Rijn L, Hagen EC, Watts RA, Gregorini G, Tervaert JW, et al. Hypotheses on the etiology of antineutrophil cytoplasmic autoantibody associated vasculitis: the cause is hidden, but the result is known. Clin J Am Soc Nephrol 2008;3:237-52.

4. Reinhold-Keller E, Herlyn K, Wagner-Bastmeyer R, Gross WL. Stable incidence of primary systemic vasculitides over five years: Results from the German Vasculitis Register. Arthritis Rheum 2005;53:93-9.

5. Watts R, Lane SE, Bentham G, Scott DG. Epidemiology of systemic vasculitis. A ten-year study in the United Kingdom. Arthritis Rheum 2000;43:414-9.

6. Gonzalez-Gay M, Garcia-Porrua C, Guerrero J, Rodriguez-Ledo P, Llorca J. The epidemiology of the primary systemic vasculitides in Northwest Spain: Implications of the Chapel Hill Consensus Conference definition. Arthritis Rheum 2003;49:388-93.

7. O’Donnell JL, Stevanovic VR, Frampton C, Stamp LK, Chapman PT. Wegener's granulomatosis in New Zealand: evidence for a latitude-dependent incidence gradient. Intern Med J 2007;37:242-6.

8. Mahr A, Artigues N, Coste J, Aouba A, Pagnoux C, Guillevin L. Seasonal variations in onset of Wegener's granulomatosis: increased in summer? J Rheumatol 2006;33:1615-22.

9. Gatenby PA, Lucas RM, Engelsen O, Ponsonby AL, Clements M. Antineutrophil cytoplasmic antibody-associated vasculitides: could geographic patterns be explained by ambient ultraviolet radiation? Arthritis Rheum 2009;61:1417-24.

10. Corral-Gudino L, Borao-Cengotita-Bengoa M, Del Pino-Montes J, Lerma-Márquez JL. Overall survival, renal survival and relapse in patients with microscopic polyangiitis: a systematic review of current evidence. Rheumatology 2011;50:1414-23.

J Rheumatol 2011;38:11; doi:10.3899/jrheum.110650 

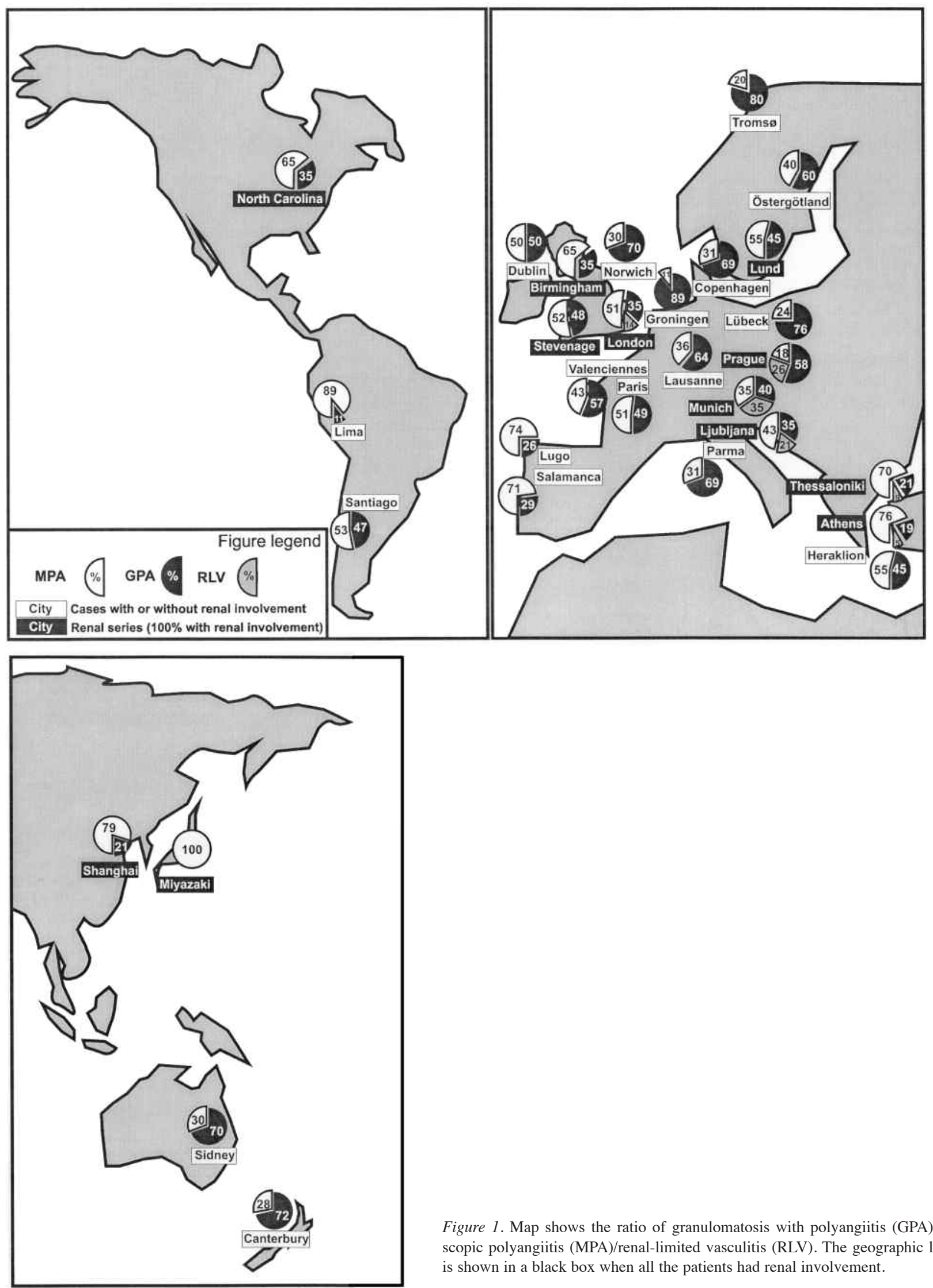

Figure 1. Map shows the ratio of granulomatosis with polyangiitis (GPA)/microscopic polyangiitis (MPA)/renal-limited vasculitis (RLV). The geographic location is shown in a black box when all the patients had renal involvement. 
Table 1. References for cited articles.

All Cases with

$\begin{array}{llll}\text { Country } & \text { City/State Reference } & \text { Renal Involvement }\end{array}$

\begin{tabular}{|c|c|c|c|}
\hline Australia & Sidney & Intern Med J 2008;38:816-23 & No \\
\hline China & Shanghai & Kidney Blood Press Res 2008;31:343-9 & Yes \\
\hline Chile & Santiago & Rev Med Chile 2005;133:273-8 & No \\
\hline Czech Republic & Prague & Kidney Blood Press Res 2005;28:144-52 & Yes \\
\hline Denmark & Copenhagen & Ann Rheum Dis 2000;59:478-82 & No \\
\hline \multirow[t]{2}{*}{ France } & Paris & Arthritis Rheum 2004;51:92-9 & No \\
\hline & Valenciennes $A$ & Am J Med 1999;106:527-33 & No \\
\hline \multirow[t]{2}{*}{ Germany } & Schlesswig-Holst & stein $\quad$ Arthritis Rheum 2005;53:93-9 & No \\
\hline & Munich $\quad \mathrm{N}$ & Nephrol Dial Transplant 2004;19:1403-11 & Yes \\
\hline \multirow[t]{3}{*}{ Greece } & Athens & Clinical Nephrology 2009;72:31-7 & Yes \\
\hline & Heraklion & Clin Exp Rheumatol 2009;27:409-15 & No \\
\hline & Thessaloniki & Ann NY Acad Sci 2005;1051:597-605 & Yes \\
\hline Ireland & Dublin & Clin Nephrol 1999;52:344-51 & No \\
\hline Italy & Parma & J Rheumatol 2006;33:1299-306 & No \\
\hline Japan & Miyazaki & Clin J Am Soc Nephrol 2006;1:2026-33 & Yes \\
\hline Netherlands & Groningen & Rheumatology $2009 ; 48: 622-5$ & No \\
\hline New Zealand & Canterbury & Rheumatology 2006;45:624-8 & No \\
\hline Norway & Tromsø & Ann Rheum Dis 2001;60:1156-7 & No \\
\hline Peru & Lima & Reumatologia $2005 ; 21: 146-50$ & No \\
\hline Slovenia & Ljubljana & Nephrol Dial Transplant 2003;18 Suppl 5: V5-v7 & Yes \\
\hline \multirow[t]{2}{*}{ Spain } & Lugo & Arthritis Rheum 2003;49:388-93 & No \\
\hline & Salamanca & Eur J Inter Med 2010;21:542-7 & No \\
\hline \multirow[t]{2}{*}{ Sweden } & Lund & Nephrol Dial Transplant 2006;21:1263-9 & Yes \\
\hline & Östergötland & J Intern Med 2009;265:496-506 & No \\
\hline Switzerland & Lausanne & J Rheumatol 2005;32:2167-72 & No \\
\hline \multicolumn{4}{|c|}{ United Kingdom } \\
\hline & Birmingham & Rheumatology 2005;44:495-501 & Yes \\
\hline & London & Am J Kidney Dis $2003 ; 41: 776-84$ & Yes \\
\hline & Norwich & Q J Med 2005;98:97-111 & No \\
\hline & Stevenage $\quad \mathrm{N}$ & Nephrol Dial Transplant 2004;19:356-64 & Yes \\
\hline United States & North Carolina $\mathrm{J}$ & J Am Soc Nephrol 1996;7:33-9 & Yes \\
\hline
\end{tabular}




\section{Correction}

Differences in the Incidence of Microscopic Polyangiitis and Granulomatosis with Polyangiitis (Wegener's). Is There a Latitudinal Gradient?

Corral-Gudino L, Borao-Cengotita-Bengoa M, Lerma-Marquez JL, del Pino-Montes J. Differences in the incidence of microscopic polyangiitis and granulomatosis with polyangiitis (Wegener's). Is there a latitudinal gradient? J Rheumatol 2011;38:2494-7. The name of author Javier del Pino-Montes was omitted in the printed edition. We regret the error.

doi:10.3899/jrheum.110650.C1 